\title{
Fuzzy Boundaries Between Post-Disaster Phases: The Case of L'Aquila, Italy
}

\author{
Diana Contreras ${ }^{1}$
}

Published online: 19 September 2016

(c) The Author(s) 2016. This article is published with open access at Springerlink.com

\begin{abstract}
A number of indices have been developed for measuring vulnerability to disasters, but little attention has been paid to recovery indices. Post-disaster periods are usually divided into four phases. The terms established by the United Nations Development Programme for post-disaster phases-relief, early recovery, recovery, and development-are used in this article. This research examines the hypothesis that the boundaries between post-disaster recovery phases are fuzzy and should be defined by the progress achieved in the recovery process, rather than by the amount of time elapsed since the event. The methodology employed involved four steps: fieldwork, mapping, identification of indicators, and assessment. The case study area was the city of L'Aquila in the Abruzzo region of central Italy, which was struck by an earthquake in April 2009. For each phase of the recovery process in L'Aquila a score was calculated based on the progress observed in 2016, 7 years after the earthquake. The highest score went to the early recovery phase (14 points), followed by the recovery phase (13 points), the development phase (12 points), and the relief phase (4 points). The results demonstrate the possibility of defining post-disaster recovery phases in an affected area based on measuring achievements through indicators rather than defining recovery phases in terms of elapsed time after a disaster.
\end{abstract}

Keywords Disaster recovery · Earthquakes .

Geographical information system (GIS) .

L'Aquila $\cdot$ Post-disaster phases $\cdot$ Spatial indicators

Diana Contreras

contrerasdi@stud.sbg.ac.at

1 Department of Geoinformatics - Z_GIS, University of Salzburg, 5020 Salzburg, Austria

\section{Introduction}

On 6 April 2009 an earthquake with a magnitude of $6.3 \mathrm{M}_{\mathrm{W}}$ and a hypocentral depth of $10 \mathrm{~km}$ struck the Italian city of L'Aquila (population 72,800). The epicenter was located in Poggio del Roio, $3.4 \mathrm{~km}$ to the southwest of the L'Aquila city center. L'Aquila is the capital of the province by the same name, and the administrative capital of the Abruzzo region in central Italy. Its location is shown in Fig. 1a, b.

The historical city was badly damaged, 67,500 people were left homeless (Alexander 2010), 1500 people were injured (202 seriously), and 308 people lost their lives. About 10,000 buildings were damaged, and between 1.5 and 3 million tons of waste were generated (Brown et al. 2011). The cost of the damage was estimated at 16 billion Euros (UNIFI 2009). Due to the extensive damage the city center was cordoned-off and declared as restricted zone until 2014, as it is depicted in Fig. 1c.

Reconstruction programs such as the Complessi Antisismici Sostenibili ed Ecocompatibili (C.A.S.E) (earthquake resistant and environmentally friendly units) project, and the Moduli Abitativi Provvisori (M.A.P) (temporary housing units) program, resulted in the construction of 5722 housing units for the homeless population in 19 new settlements distributed around the city at various locations within 1 year from the earthquake (Contreras et al. 2013). The C.A.S.E and M.A.P. projects resettled 11,923 and 2482 displaced residents from L'Aquila, respectively. Six months after the earthquake only $25 \%$ of the displaced inhabitants were able to return to their former homes (Gigantesco et al. 2013). One year after the earthquake 5000 of the survivors who used to live in the city center were still housed in hotels, 15,000 in provisional housing, and 27,000 
RESTRICTED ZONE AFTER THE EARTHQUAKE (2009 - 2010)

(c)

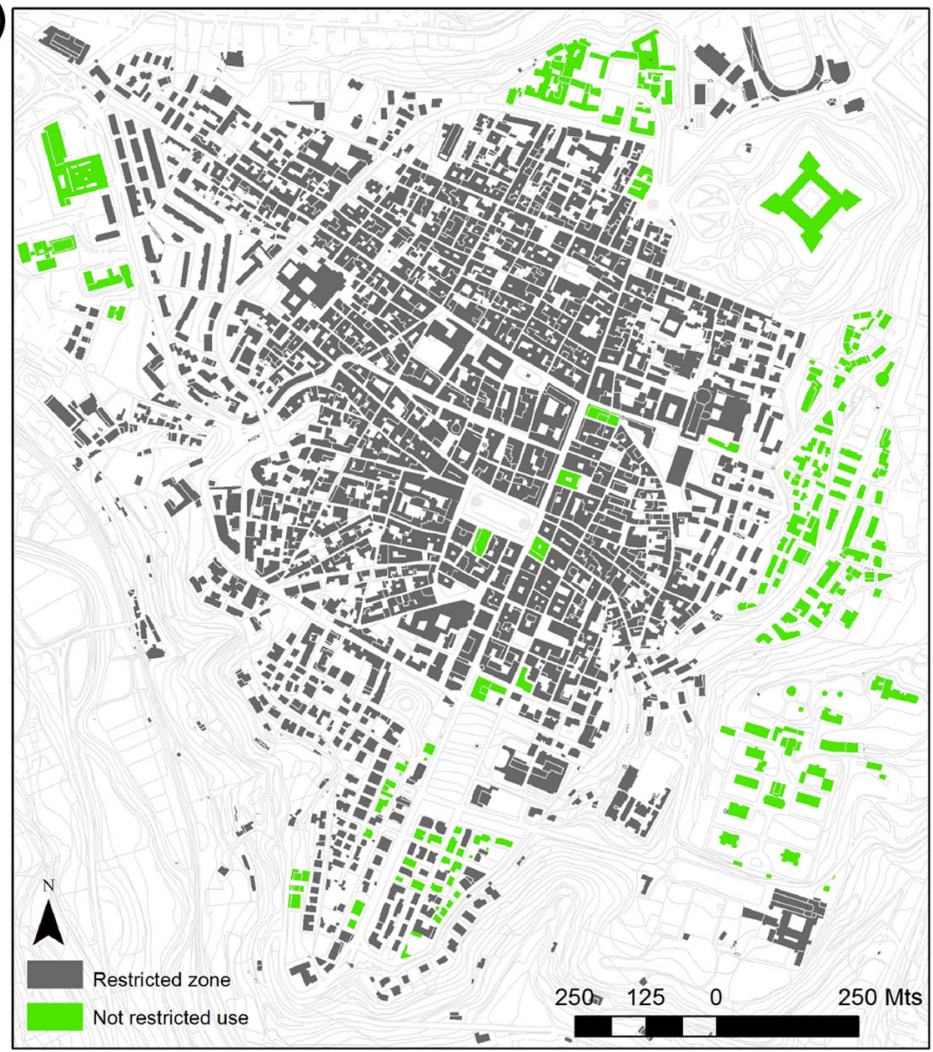

L'AQUILA - ITALY

(a)

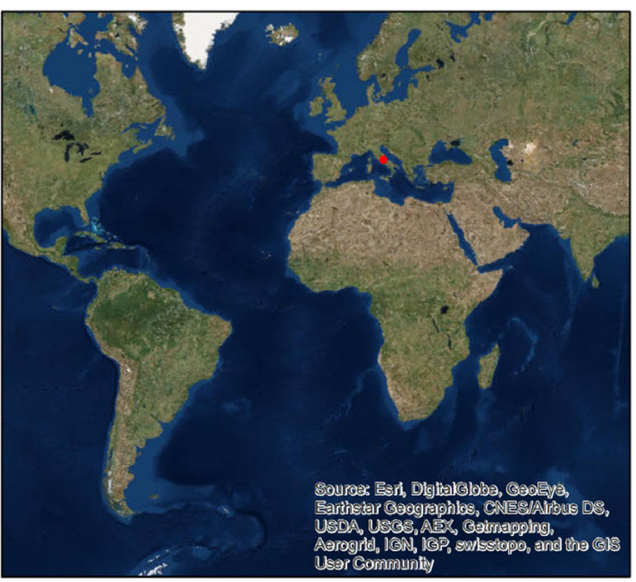

(b)

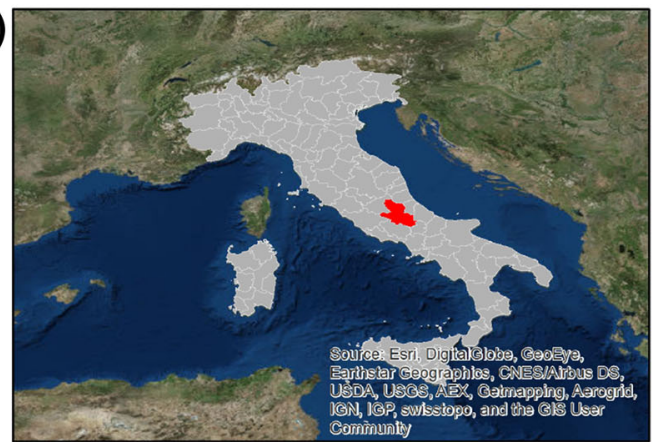

Fig. 1 a, b Location of the case study area: L'Aquila, Italy; c restricted zone in L'Aquila after the earthquake on 6 April 2009

in rented accommodation with a government grant of between 600 and 800 Euros per month.

This expensive housing resettlement solution resulted in a number of problems including a lack of basic services, lack of urban facilities (for example, churches, schools, pharmacies, post offices, supermarkets, social centers, sports centers), lack of spatial connectivity (Contreras et al. 2013), social fragmentation (Geipel 1979; Forino 2014), and questionable ecological values (Alexander 2012). This artificial resettlement "sprawl" did not consider either the social or spatial characteristics of L'Aquila, nor the centuries-old relations between the historical center and its surrounding neighborhoods (Forino 2014).

The recovery of L'Aquila has unfortunately been surrounded by political intrigues and scandals, as well as legal and administrative failures. In 2012, six Italian scientists were convicted of manslaughter with 6 years in prison for failing to predict the deadly earthquake and for giving incomplete and contradictory information to the residents. The court stated that they were not able to accurately communicate the risk in 2009 (BBC 2014). Eventually, the sentence was overturned because it did not have a solid legal basis. The mayor of L'Aquila resigned several times and by 2014 he was under investigation. The person in charge of allocating funds was also accused of and then acquitted for mismanagement of funds. The conflict between this person and the mayor of L'Aquila contributed to the delay of the reconstruction process. At the same time other debates were going on regarding the cost of scaffolding (Ciorra 2014) and the dwellings in the new settlements (Alexander 2012). Discussions also took place within the provincial government with respect to the recovery of L'Aquila, which included the idea of relocating the whole city to some available public land.

\section{Literature Review}

For the purpose of this article, post-disaster recovery is defined as a complex multidimensional, long-term process involving planning, financing, decision making, and reconstruction. The recovery process is aimed at restoring sustainable living conditions to a community or an area that has been strongly affected in the physical, social, economic, institutional, cultural, and ecological dimensions as a result of vulnerability that existed prior to an event. In 
such a situation the recovery process must not only involve the reconstruction of buildings and the restoration of infrastructure, but also address the interactions between diverse groups and institutions with the aim of rebuilding people's lives and livelihoods, as well as restoring cultural assets and ecological conditions (Contreras et al. 2014).

Although post-disaster recovery is an uncertain and often conflict-laden process that is nonlinear and has no clear boundaries, it is usually divided into four phases. A summary of the terms assigned by different authors to each recovery phase is presented in Fig. 2.

For this research the terms established by the United Nations Development Programme (UNDP)—relief, early recovery, recovery, and development phases-were adopted (UNDP 2008). During the relief phase the priority is to save the lives of people through the deployment of searchand-rescue (SAR) task forces (Kates and Pijawka 1977; Alexander 2006). It is critical to include a building damage survey (Contreras 2009) to determine the level of damage, and badly damaged buildings need to be evacuated and demolished (Brown et al. 2010). A needs assessment is then required to make an initial estimate of the number of people left homeless by the earthquake, the number of temporary shelters required (Brown et al. 2010), and the type of humanitarian aid required. Secondary impacts due to the earthquake (for example, landslides or fires) need to be dealt with as quickly as possible. Essential services need to be restored and the rehabilitation of roads (Alexander 2006) and the environment needs to be set in progress (Brown et al. 2010; Alexander 2006).

The early recovery phase aims to return the community to normal life by completing the removal of debris, the rehabilitation of roads, and the demolition of damaged buildings (Brown et al. 2010; Alexander 2006) and starting the removal of temporary shelters. The reconstruction and/ or repair of buildings, roads, and bridges should start during this phase (Alexander 2006), and any pre-impact recovery plan should be implemented or, in the absence of a preexisting plan, a new recovery plan formulated. The restoration of essential services should be completed. Urban facilities need to be reactivated to enable businesses to continue to operate and support the recovery.

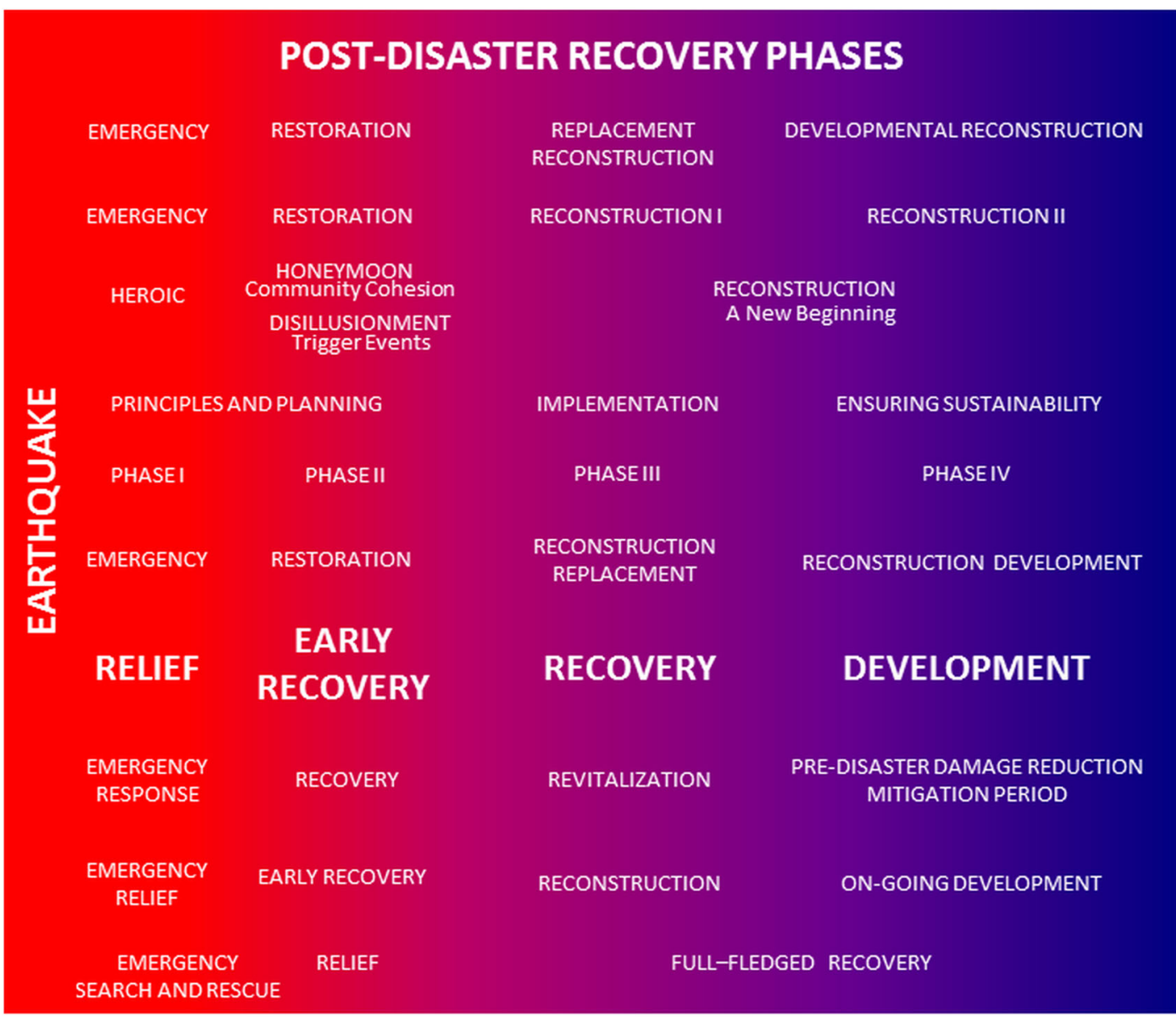

\section{AUTHORS}

Kates and Pijawka (1977)

Hogg

(1980)

SAMHSA

(2000)

Shaw et al. (2004)

Karatani \& Hayashi (2004)

Vale \& Campanella (2005)

\section{UNDP}

(2008)

Murai

(2008)

Brown etal.

(2010)

Honjo (2011)

Fig. 2 Names assigned to post-disaster recovery phases by different authors. Source Adapted from UNDP (2008) 
The main objective during the recovery phase is for the disaster area to return to normality (Alexander 2006) through continuing implementation of the recovery plan, but with the inclusion of modifications based on specific experience gained following the event. Essential services and urban facilities should be fully functional. Social differentiation rather than social equity is prominent during this phase because people on high incomes will have easier access to credit and are likely to have been better insured than those on low incomes, who may therefore be less resilient (Alexander 2006). Reconstruction and/or repair of buildings and environmental rehabilitation continue during the recovery phase, and work starts on the restoration of parks and monuments (Brown et al. 2010). The construction of bridges and new roads tapers off and the removal of temporary shelters finishes (Brown et al. 2010). Changes must be monitored in building use and in housing density, especially in areas with high levels of damage. In most cases the recovery process stops in the recovery phase, without including the experience gained following the disaster, which encourages emergent vulnerability and reduce the possibility to build back better.

The development phase goes beyond the state that existed prior to the event, or the state that would have existed had the event not occurred (Chang 2009), although few of the affected areas are likely to reach this stage with most areas remaining in the recovery phase. Monuments are erected to commemorate the disaster (Alexander 2006). In the development phase assessments are made of the way the recovery phase was implemented and of lessons learned that should be included in future recovery plans. The construction of buildings, parks, and monuments gradually decreases, and rehabilitation of the environment continues (Brown et al. 2010). In the case of the essential services, business continuity plans need to be established to allow continuity of business operations, or to provide for redundancies. Building codes must be formulated and applied; buildings need to be reinforced, giving priority to facilities required to respond to emergencies. Urban facilities need to have emergency and contingency plans in place, and businesses require continuity plans. During this phase changes in urban land use, building density, parks, and roads need to be evaluated in terms of the lessons learned from the disaster. Economic growth starts during the development phase with the process of local or regional regrouping (Kates and Pijawka 1977).

Kates and Pijawka (1977) divided recovery processes into four time periods: an emergency period lasting between a few days and about 4 weeks; a restoration period lasting from 2 to 9 months, a replacement-reconstruction period lasting from 3 to 20 years, and finally, a phase of developmental reconstruction of undefined length. This model was formulated based on experience gained from the recovery processes in Rapid City, South Dakota (1972 flood), San Francisco, California (1906 earthquake), Anchorage, Alaska (1964 earthquake), and Managua, Nicaragua (1972 earthquake). However, when Hogg (1980) tested the Kates and Pijawka model with the recovery process after the 1976 Venzone earthquake in Friuly, northeast Italy, the first phase took twice as long as the Kates and Pijawka model suggested and the second phase also lasted longer, while the third phase had not been started 3 years later. Hogg eventually concluded that the differences in the time periods were due to the different size and needs of the small town of Venzone following the earthquake, compared with the cities on which the model by Kates and Pijawka was tested.

Karatani and Hayashi (2004) also considered four phases for the recovery process after the 1995 Hanshin-Awaji or Kobe earthquake, but included an additional predisaster phase designated "Phase 0 " that started 2 years before the earthquake. According to these authors, the relief phase takes 9 months, the early recovery phase takes 3 years, and the recovery phase takes 4 years. Other authors such as Brown et al. (2010) defined some particular activities that should start, continue, or be completed in each phase, without suggesting a time frame for each phase. The Substance Abuse and Mental Health Services Administration in the United States (SAMHSA 2000) considers a predisaster phase of warning and threat, before the phases of disaster recovery in terms of collective reactions: heroic, honeymoon (community cohesion), disillusionment (trigger events/anniversary reactions), and reconstruction (a new beginning; setback; working through grief; coming to terms).

More vulnerable zones have longer recovery phases (Wisner 2004). Each post-disaster phase is characterized by unique functional and operational requirements (Kates and Pijawka 1977). The recovery phase is determined by the unique history of an area (Karatani and Hayashi 2007). The assessment of recovery processes following an earthquake needs to be based on specific indicators in order to ensure objectivity and comparability (Shohei 2007). Aldrich (2012) considered six main factors and resources that determine recovery rates: the provision of aid to survivors, the level of damage, the population density, human factors (such as education, job skills, employment experience), social factors, and capital (savings) available.

\section{Hypothesis}

Post-disaster periods are usually divided into four phases. This research examines the hypothesis that the boundaries between post-disaster recovery phases are fuzzy and that recovery phases overlap. It is proposed that the post- 
disaster recovery phase attained in an affected area should be defined by the progress achieved in the recovery process, as measured by specific indicators, rather than by the amount of time elapsed since the event.

\section{Methodology}

The methodology for this research involved four steps: (1) fieldwork in L'Aquila; (2) mapping of earthquake recovery; (3) selection of earthquake recovery indicators; and (4) assessment of earthquake recovery in L'Aquila.

\subsection{Fieldwork}

Four field visits have been made to L'Aquila in 2010, 2012, 2014, and 2016 that is one, three, five and 7 years after the earthquake in 2009. The main activities during the field visits involved (1) visits around and to the former restricted zone; (2) visits to the new settlements around L'Aquila; (3) the collection of cadastral data and aerial photographs of L'Aquila; and (4) interviews with 4 members of the Department of Civil Protection in 2010, and 4 members of the Settore Ricostruzione Pubblica-Ufficio Progettazione (Office of Public Reconstruction-Office of Planning) in 2014.

A monitoring schedule, including details of the tools used to collect the data, was an essential part of the research. This schedule was formulated at the start of the study, but subsequently adjusted according to the availability of the means, resources, and data required for the research (Contreras et al. 2016). This monitoring schedule is outlined in Table 1.

\subsection{Mapping of Earthquake Recovery in L'Aquila}

This activity entailed five steps: (1) selection of a sampling area: the restricted zone after the earthquake (Fig. 1c); (2) selection of the categories that compound the indicators in the physical and socioeconomic dimensions; (3) analysis of the progress of recovery using spatial indicators: changes in building use (residential, commercial, transport, recreation, religious, hospital, office, educational, industrial, sports, hotel, monument, and not inhabited) before 2009 and after the earthquake in 2010, 2012, 2014, and 2016 as well as changes in building condition (new buildings, construction ongoing, partially enabled, reconstructed, reconstruction ongoing, earthworks, reconstruction projected, repaired, debris removed, propped, inhabited, damaged, restricted use, and demolished) for the same years (Contreras et al. 2014; Contreras and Blaschke 2016); (4) combining of results with weights allocated by experts in disaster management, geoinformatics, and remote sensing to the key spatial categories and indicators in a recovery index; and (5) determining the hotspots of recovery in L'Aquila based on the building use and building condition of the buildings in the time of the fieldwork and their contribution to the recovery process

Table 1 Monitoring schedule of the post-disaster recovery progress in L'Aquila, Italy. Source Adapted from Contreras and Blaschke (2016)

\begin{tabular}{|c|c|c|c|c|c|c|c|}
\hline \multicolumn{2}{|c|}{ Timeline } & \multicolumn{4}{|c|}{ Remote sensing (RS) } & \multirow{2}{*}{$\begin{array}{l}\text { Ground observations (GO) } \\
\text { Tools }\end{array}$} & \multirow{2}{*}{$\begin{array}{l}\text { Geographic information system (GIS) } \\
\text { Software/Applications }\end{array}$} \\
\hline $\mathrm{N}^{*}$ & Year & Month & Sensor & Analysis & Month & & \\
\hline 1 & 2010 & & & & April & $\begin{array}{l}\text { GPS } \\
\text { Analogue maps } \\
\text { Interviews }\end{array}$ & $\begin{array}{l}\text { Arc GIS 9.3-10 } \\
\text { Google Earth } \\
\text { Google Maps }\end{array}$ \\
\hline 2 & 2011 & September & Quickbird & $\begin{array}{l}\text { OBIA } \\
\text { GIS }\end{array}$ & & & \\
\hline 3 & 2012 & & & & September & $\begin{array}{l}\text { GPS } \\
\text { Analogue maps }\end{array}$ & $\begin{array}{l}\text { Arc GIS } 10.1 \\
\text { Google Earth } \\
\text { Google Maps }\end{array}$ \\
\hline 5 & 2014 & & & & April & $\begin{array}{l}\text { GPS } \\
\text { Analogue maps } \\
\text { Interviews }\end{array}$ & $\begin{array}{l}\text { Arc GIS } 10.3 \\
\text { Google Earth } \\
\text { Google Maps }\end{array}$ \\
\hline $\begin{array}{l}7 \\
10\end{array}$ & $\begin{array}{l}2016 \\
2019 * *\end{array}$ & April & Quickbird & $\begin{array}{l}\text { OBIA } \\
\text { GIS }\end{array}$ & $\begin{array}{l}\text { July } \\
\text { April }\end{array}$ & $\begin{array}{l}\text { GPS } \\
\text { Analogue maps } \\
\text { Interviews }\end{array}$ & $\begin{array}{l}\text { Arc GIS } 10.4 \\
\text { Google Earth } \\
\text { Google Maps }\end{array}$ \\
\hline
\end{tabular}

* Number of years after the earthquake

** Fieldwork planned 
according to the experts. Building use before the earthquake is based on the observation of the announcements above the door of the stores and the photographs taken during the fieldwork, Google Maps, as well as information extracted from photographs available in the 3D model of the city of L'Aquila in Google Earth. The hotspots of recovery in the city center of L'Aquila in 2010, 2012, 2014, and 2016 are depicted in Fig. 3.

\subsection{Selection of Earthquake Recovery Indicators}

The recovery indicators were selected based on a review of the literature on the topic of recovery indicators after earthquakes and on the basis of experience gained through fieldwork and mapping. The selection of indicators was based on the indicators taken into account by other authors to measure the progress of the recovery after the 1976 earthquake in Venzone (Hogg 1980) and the 1995 HanshinAwaji or Kobe earthquake (Karatani and Hayashi 2007; Chang 2009; Honjo 2011), the 2004 Indian Ocean tsunami, and the 2005 Pakistan earthquake (Brown et al. 2010). The selected indicators were then classified into physical, social, economic, institutional, cultural, and ecological dimensions. Each dimension contains indicators or variables that can be measured in different units during different phases of the post-disaster recovery.

\subsection{Assessment of Earthquake Recovery in L'Aquila}

In order to determine which recovery phase a particular zone has reached it is desirable (but not essential) to have quantitative data for each indicator and/or variable or category. This enables specific indicators of recovery to be monitored through time.

The proposed method uses the framework derived from existing studies to estimate which post-disaster phase an area is in. Rather than using the particular quantities measured for each indicator, it makes use of a binary numeral system (using two values 0 and 1) to indicate whether or not the activity represented by a particular indicator is ongoing in the post-disaster phases, according to the UNDP (2008) definition. The post-disaster recovery phases are specified at the top of Table 2. The colors in the table indicate the post-disaster recovery phases in which each indicator should be measured, or the phase during which each activity should take place. The value " 1 " is assigned to indicators in phases in which the activities have taken place. The value " 0 " is assigned when the activity should have occurred in the analyzed area but in reality did not occur. Finally, the total score in each phase is compared in order to establish which post-disaster phase each area has reached. This assessment method was applied to
L'Aquila -instead of considering all of the indicators derived from the literature review, only those for which primary or secondary data were available were used. The post-disaster phase with the highest score shows the phase attained at L'Aquila 5 years after the earthquake.

\section{Results}

A total of 79 indicators were selected to define the postdisaster recovery phase achieved by L'Aquila (Table 2). The progress of each indicator in the recovery of L'Aquila is evaluated for 2014 and a value of " 1 " or " 0 " is assigned according to the criteria described in the methodology section.

The highest score (14 points) was obtained for the early recovery phase, followed by the recovery phase (13 points), the development phase (12 points), and the relief phase (4 points).

Electricity and gas supplies, as well as telephone lines, were reported to have been damaged by the L'Aquila earthquake (Donadio and Povoledo 2009). During the fieldwork the gas supplies and road networks appeared to be the aspects of infrastructure worst affected by the earthquake. Esposito et al. (2013) reported that testing and repair of more than $70 \%$ of the gas network in L'Aquila was completed within 3 months of the earthquake, but work on these facilities was observed to be still in progress during the first field visit to the area in 2010. Thus a value of 1 was assigned to the gas facilities restoration indicator for the early recovery and recovery phases.

With regard to the road network, 1 year after the earthquake in 2010 there was no access available to the restricted zone in the city center. Some of the roads were open by the 2012 field visit, but access was guarded by the army and police. Seven years after the earthquake in 2016 it is possible to walk around the city center, but some secondary streets still are closed, due to the ongoing works. Debris could still be observed at the city center of L'Aquila even 5 years after the earthquake, but it was not blocking the streets anymore. Therefore, a value of " 0 " was assigned to the roads obstructed indicator for the relief phase, while the indicators debris removed and roads opened got a value of "1" for the early recovery phase. The bus terminal was damaged by the earthquake, but the repair works took a year to complete. Some bus stops were still not in use in 2010, but by 2014 most of them were. So the value of " 1 " was assigned to the connectivity indicator for the early recovery and recovery phases, though the service frequencies of the routes that connect the new settlements and central L'Aquila still need to be increased. Nevertheless, in 2016 it was observed that there are a high number 


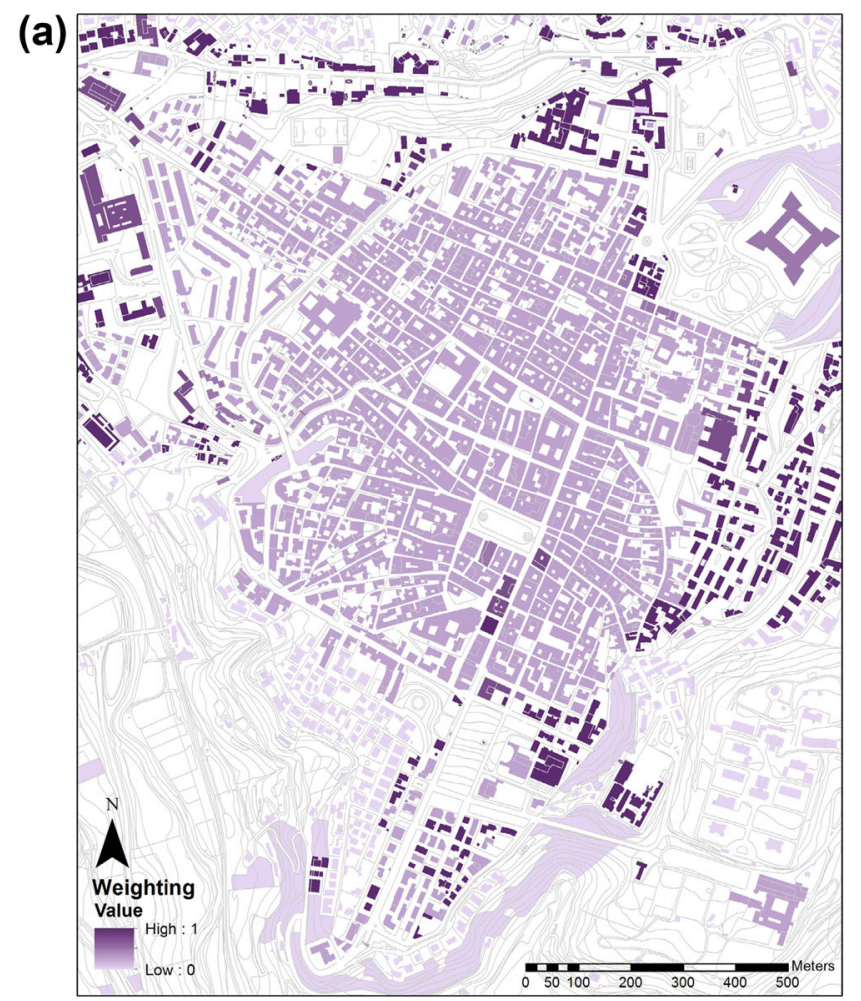

(b)

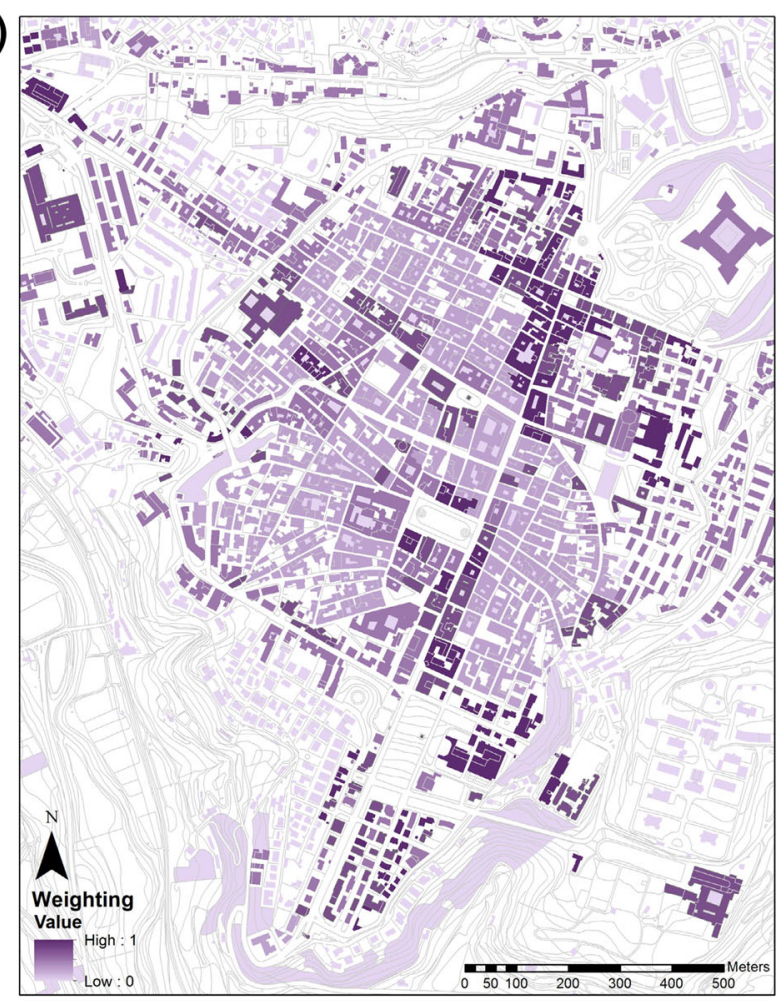

(c)

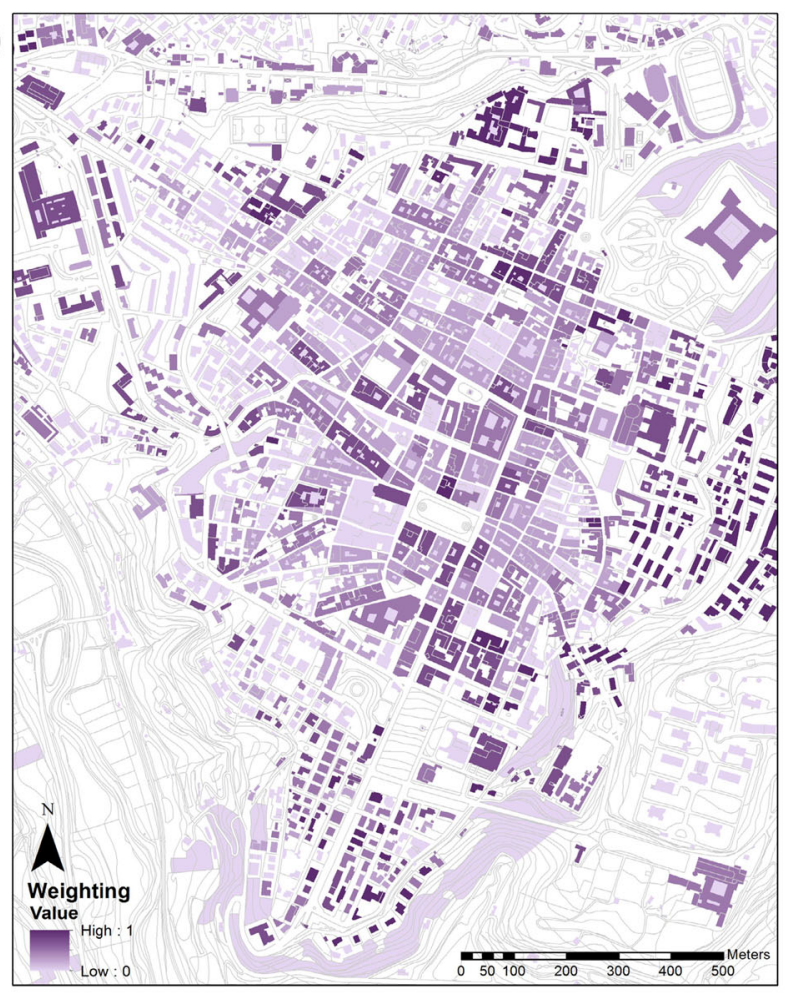

(d)

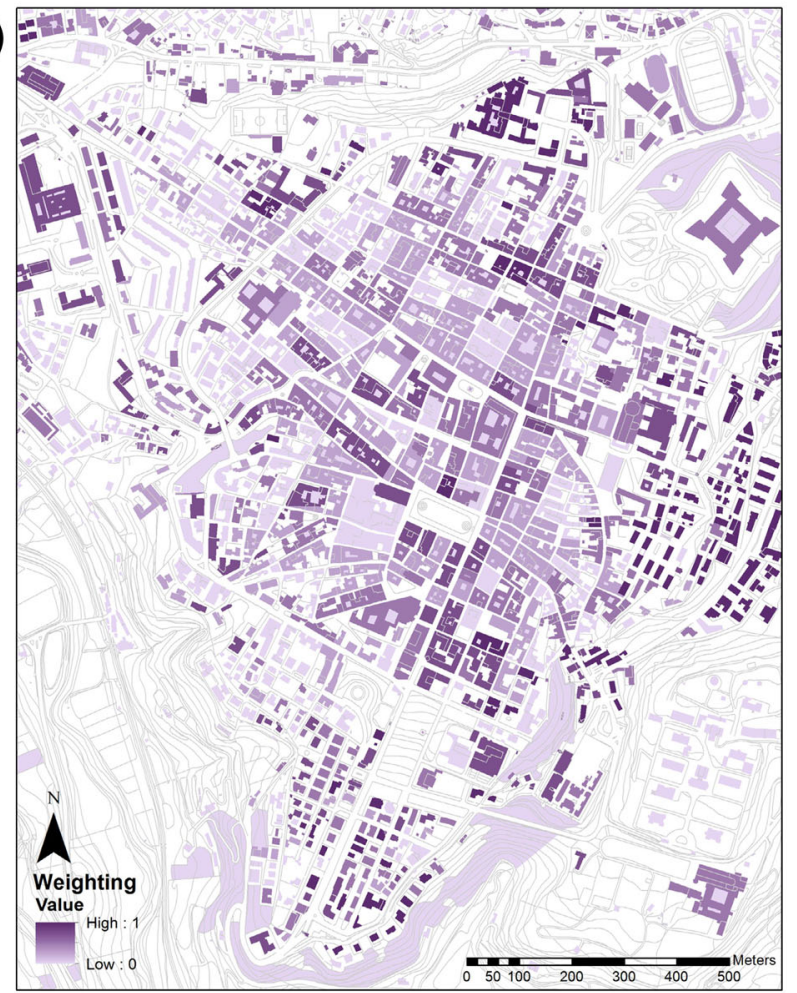

Fig. 3 Hotspots of recovery in the city center of L'Aquila, Italy after the 6 April 2009 earthquake in a 2010; b 2012; c 2014; and d 2016. Source Adapted from Contreras et al. (2016) 
Table 2 Assessment of post-disaster earthquake recovery in L'Aquila, Italy, after 7 years in 2016

\begin{tabular}{|c|c|c|c|c|c|c|c|}
\hline D & $\mathbf{C}$ & & INDICATORS & RELIEF & $\begin{array}{c}\text { EARLY } \\
\text { RECOVERY }\end{array}$ & RECOVERY & DEVELOPMENT \\
\hline \multirow{5}{*}{ 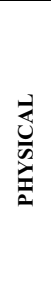 } & \multirow{5}{*}{ 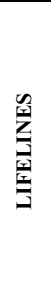 } & \multirow{5}{*}{ Gas facilities } & Damaged facilities & 0 & & & \\
\hline & & & Provisional measures & 0 & 0 & & \\
\hline & & & Restoration & & 1 & 1 & \\
\hline & & & $\begin{array}{l}\text { Emergency and/or } \\
\text { business continuity plan }\end{array}$ & & & & 0 \\
\hline & & & $\begin{array}{l}\text { Improvements in } \\
\text { capacity }\end{array}$ & & & & 0 \\
\hline \multirow[t]{24}{*}{ D } & $\mathbf{C}$ & & INDICATORS & RELIEF & $\begin{array}{c}\text { EARLY } \\
\text { RECOVERY } \\
\end{array}$ & RECOVERY & DEVELOPMENT \\
\hline & \multirow{13}{*}{ 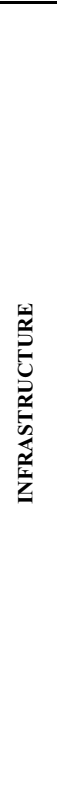 } & \multirow{7}{*}{ Roads } & Roads obstructed & 0 & & & \\
\hline & & & Debris removed & 0 & 1 & & \\
\hline & & & $\begin{array}{l}\text { Acquisition of new } \\
\text { and/or additional spaces } \\
\text { to deposit debris }\end{array}$ & $\mathbf{0}$ & 0 & & \\
\hline & & & Roads opened & & 1 & & \\
\hline & & & Connectivity & & 1 & 1 & 1 \\
\hline & & & $\begin{array}{l}\text { Emergency and/or } \\
\text { business continuity plan }\end{array}$ & & & & 0 \\
\hline & & & $\begin{array}{l}\text { New connections to the } \\
\text { affected area }\end{array}$ & & & & 1 \\
\hline & & \multirow{6}{*}{$\begin{array}{l}\text { Bus } \\
\text { stations/stops }\end{array}$} & Availability & 0 & & & \\
\hline & & & Repaired & 0 & 1 & 1 & \\
\hline & & & Reinforcement works & & & 0 & 0 \\
\hline & & & $\begin{array}{l}\text { Emergency and/or } \\
\text { business continuity plan }\end{array}$ & & & & 0 \\
\hline & & & $\begin{array}{l}\text { Improvements in } \\
\text { capacity }\end{array}$ & & & & 1 \\
\hline & & & $\begin{array}{l}\text { New stations/stops that } \\
\text { serve the affected area }\end{array}$ & & & & 1 \\
\hline & \multirow{10}{*}{ 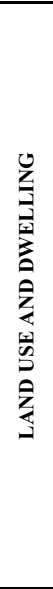 } & \multirow{8}{*}{ Dwelling } & Damaged buildings & 1 & & & \\
\hline & & & Building inspectors & 0 & & & \\
\hline & & & $\begin{array}{l}\text { Secondary effects (fires, } \\
\text { landslides, and so on) }\end{array}$ & 0 & & & \\
\hline & & & Homeless people & 0 & 0 & & \\
\hline & & & Temporary shelters & 0 & 0 & & \\
\hline & & & $\begin{array}{l}\text { Repaired } \\
\text { houses/buildings } \\
\text { reconstructed }\end{array}$ & & 1 & 1 & \\
\hline & & & $\begin{array}{l}\text { Number of reinforced } \\
\text { houses }\end{array}$ & & & 1 & 1 \\
\hline & & & $\begin{array}{l}\text { New houses constructed } \\
\text { with seismic isolation }\end{array}$ & & & & 1 \\
\hline & & \multicolumn{2}{|c|}{ Change in building condition } & $\mathbf{0}$ & 1 & 1 & 1 \\
\hline & & \multicolumn{2}{|c|}{ Change in building use } & 0 & 1 & 1 & 1 \\
\hline \multirow{5}{*}{ 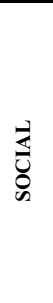 } & \multirow{5}{*}{ 疍 } & \multirow{5}{*}{ Health facilities } & $\begin{array}{l}\text { Availability of health } \\
\text { facilities }\end{array}$ & 0 & & & \\
\hline & & & Field hospitals required & 0 & & & \\
\hline & & & $\begin{array}{l}\text { Health facilities } \\
\text { repaired }\end{array}$ & & 1 & & \\
\hline & & & Reinforced & & & 0 & 0 \\
\hline & & & $\begin{array}{l}\text { Emergency and/or } \\
\text { business continuity plan }\end{array}$ & & & & 0 \\
\hline
\end{tabular}


Table 2 continued

\begin{tabular}{|c|c|c|c|c|c|c|c|}
\hline D & $\mathrm{C}$ & \multicolumn{2}{|r|}{ INDICATORS } & \multirow[t]{2}{*}{ RELIEF } & \multirow[t]{2}{*}{$\begin{array}{c}\text { EARLY } \\
\text { RECOVERY }\end{array}$} & \multirow[t]{2}{*}{ RECOVERY } & DEVELOPMENT \\
\hline & & & $\begin{array}{l}\text { Improvements in } \\
\text { capacity }\end{array}$ & & & & 0 \\
\hline & & & $\begin{array}{l}\text { New services to the } \\
\text { affected area }\end{array}$ & & & & o \\
\hline & \multirow{7}{*}{ 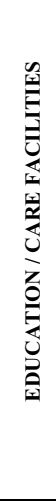 } & \multirow{7}{*}{$\begin{array}{l}\text { Day cares, } \\
\text { kindergartens, } \\
\text { schools, } \\
\text { universities, } \\
\text { nursing homes, } \\
\text { sports facilities }\end{array}$} & $\begin{array}{l}\text { Availability of } \\
\text { education, care and } \\
\text { sport facilities }\end{array}$ & 1 & & & \\
\hline & & & Temporary structures & 0 & & & \\
\hline & & & Repaired & 0 & 1 & & \\
\hline & & & Reinforced & & & 0 & 0 \\
\hline & & & $\begin{array}{l}\text { Emergency and/or } \\
\text { business continuity plan }\end{array}$ & & & & $\mathbf{0}$ \\
\hline & & & $\begin{array}{l}\text { Improvements in } \\
\text { capacity }\end{array}$ & & & & 1 \\
\hline & & & $\begin{array}{l}\text { New services to the } \\
\text { affected area }\end{array}$ & & & & 0 \\
\hline & \multirow{5}{*}{\multicolumn{2}{|c|}{ MIGRATION }} & Emigration rate & & & 1 & $\mathbf{0}$ \\
\hline & & & $\begin{array}{l}\text { Incentives for relocating } \\
\text { people }\end{array}$ & & & 1 & $\mathbf{0}$ \\
\hline & & & Relocation & & & 1 & 0 \\
\hline & & & $\begin{array}{l}\text { Satisfaction with the } \\
\text { relocation }\end{array}$ & & & 0 & 0 \\
\hline & & & $\begin{array}{l}\text { Satisfaction with the } \\
\text { recovery process }\end{array}$ & & & 0 & 0 \\
\hline \multirow{14}{*}{ 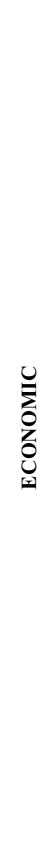 } & \multirow{14}{*}{ 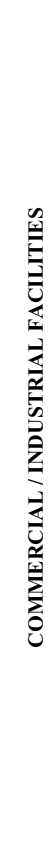 } & \multirow{7}{*}{$\begin{array}{l}\text { Supermarkets, } \\
\text { industries, } \\
\text { companies and } \\
\text { banks. }\end{array}$} & $\begin{array}{l}\text { Availability of } \\
\text { commercial and } \\
\text { industrial facilities }\end{array}$ & 1 & & & \\
\hline & & & Repaired & & 1 & & \\
\hline & & & $\begin{array}{l}\text { Creation of areas free of } \\
\text { taxes }\end{array}$ & & & & 1 \\
\hline & & & Reducction in taxes & & & & 0 \\
\hline & & & Job openings per month & & & 1 & 0 \\
\hline & & & Job applicants' & & & 1 & 0 \\
\hline & & & $\begin{array}{l}\text { Job openings per month } \\
\text { for the most vulnerable } \\
\text { population }\end{array}$ & & & 0 & 0 \\
\hline & & & Hotels available & 0 & & & \\
\hline & & & Hotels repaired & & 1 & & \\
\hline & & & Reinforced & & & 0 & 0 \\
\hline & & & Hotel reservation rates & & & 1 & 0 \\
\hline & & Hotels & $\begin{array}{l}\text { Emergency and/or } \\
\text { business continuity plan }\end{array}$ & & & & $\mathbf{0}$ \\
\hline & & & $\begin{array}{l}\text { Improvements in } \\
\text { capacity }\end{array}$ & & & & o \\
\hline & & & $\begin{array}{l}\text { New services to the } \\
\text { affected area }\end{array}$ & & & & 0 \\
\hline
\end{tabular}


Table 2 continued

\begin{tabular}{|c|c|c|c|c|c|c|c|}
\hline D & $\mathrm{C}$ & & INDICATORS & RELIEF & $\begin{array}{c}\text { EARLY } \\
\text { RECOVERY }\end{array}$ & RECOVERY & DEVELOPMENT \\
\hline & \multirow{7}{*}{ 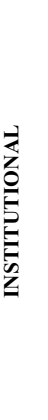 } & \multirow{7}{*}{$\begin{array}{l}\text { Public } \\
\text { buildings }\end{array}$} & Availability & 0 & & & \\
\hline & & & $\begin{array}{l}\text { Temporary structures } \\
\text { required }\end{array}$ & 0 & 0 & & \\
\hline & & & Repaired & & 0 & & \\
\hline & & & Reinforced & & & 0 & $\mathbf{0}$ \\
\hline & & & $\begin{array}{l}\text { Emergency and/or } \\
\text { business continuity plan }\end{array}$ & & & & 0 \\
\hline & & & $\begin{array}{l}\text { Improvement of the } \\
\text { capacity }\end{array}$ & & & & 0 \\
\hline & & & $\begin{array}{l}\text { New public buildings in } \\
\text { the affected area }\end{array}$ & & & & 1 \\
\hline \multirow{5}{*}{ 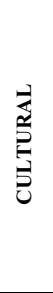 } & \multirow{5}{*}{\multicolumn{2}{|c|}{$\begin{array}{l}\text { Monuments } \\
\text { /conservation buildings }\end{array}$}} & Availability & 0 & & & \\
\hline & & & Repaired & & 1 & & \\
\hline & & & Reinforced & & & 1 & \\
\hline & & & $\begin{array}{l}\text { Emergency and/or } \\
\text { business continuity plan }\end{array}$ & & & $\mathbf{0}$ & 0 \\
\hline & & & $\begin{array}{l}\text { New services to the } \\
\text { affected area }\end{array}$ & & & 0 & 0 \\
\hline \multirow{6}{*}{ 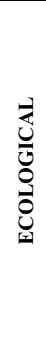 } & \multirow{6}{*}{\multicolumn{2}{|c|}{ Open spaces and parks }} & Availability & $\mathbf{0}$ & & & \\
\hline & & & Structures repaired & & 1 & & \\
\hline & & & Reforestation task & & & 0 & 0 \\
\hline & & & $\begin{array}{l}\text { Emergency and/or } \\
\text { business continuity plan }\end{array}$ & & & & 0 \\
\hline & & & $\begin{array}{l}\text { New services to the } \\
\text { affected area }\end{array}$ & & & & $\mathbf{0}$ \\
\hline & & & Environmental reserve & & & & 0 \\
\hline & & & TOTAL & 4 & 14 & 13 & 12 \\
\hline
\end{tabular}

$D$ Dimensions, $C$ Categories

of buses between L'Aquila and Rome, compensating for the shortfalls in train frequencies.

In 2016 it was still possible to find buildings and houses in L'Aquila that were in the same, or even worse, condition as immediately after the earthquake in 2009 (Fig. 4a, b, g). This is the reason to assign the value of " 1 " to the damaged buildings indicator in the relief phase. Other buildings had been demolished, repaired, reconstructed, or were undergoing reconstruction (Fig. 4c, d). Therefore a value of "1" was assigned to the repaired houses/buildings reconstructed indicator for the early recovery and recovery phases. While the Government Palace in the city center of L'Aquila (Fig. 4e) had been relocated (Fig. 4f), damaged houses in the city center (Fig. 4g) had been reconstructed in new settlements in the outskirts of the city (Fig. 4h). In the sampling that included 753 buildings in the former restricted zone in the city center of L'Aquila, 163 buildings (22\% of the buildings considered in the sampling area) had been reconstructed by 2016, an encouraging sign of recovery in the city, taking into account that there was no reconstructed buildings by 2012 (3 years after the earthquake).

Considering the same sampling area and the same number of buildings (753), it was found that the percentage of buildings that were partly enabled (the building is propped, stores are functioning in the ground floor, but the other floors are empty) had plummeted from $4 \%$ (29) to slightly over $1 \%$ (11) between 2010 and 2016. The percentage of buildings under reconstruction rocketed to $20 \%$ (150) in 2016 from just over $5 \%$ (41) in 2010. The percentage of buildings for which reconstruction was planned (announced in a billboard) rose from to $2 \%$ (13) in 2012 to $4 \%(29 \%)$ in 2014 , but fell to $3 \%$ (24) in 2016. The percentage of propped buildings (still requiring structural support) rocketed to over $29 \%$ (220) in 2012 from just $4 \%$ (31) in 2010. However, the percentage of propped buildings dropped to $22 \%$ (165) in 2014 and $16 \%$ (121) in 2016. The percentage of buildings with restricted use had been steadily falling from $82 \%$ (621) in 2010, to $44 \%$ (332) in 2012, $9 \%$ (67) in 2014, and $7 \%$ (52) in 2016, 
Fig. 4 Progress of rebuilding in L'Aquila, Italy, after the 6 April 2009 earthquake: a Students' dormitory along via XX Settembre in 2010 (one year after the earthquake); b Students' dormitory along via XX Settembre in 2016 (seven years after the earthquake); c Church Santa Maria del Sufragio in 2010; d Church Santa Maria del Sufragio in 2016; e Government Palace in 2009 (Photograph by David Alexander); f Government Palace relocated (2014); g damaged houses in the city center (2014); $\mathbf{h}$ new houses in Paganica (2014). Photographs by D. Contreras (a)

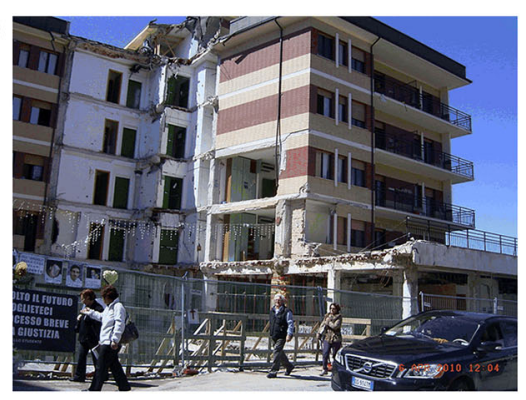

(c)

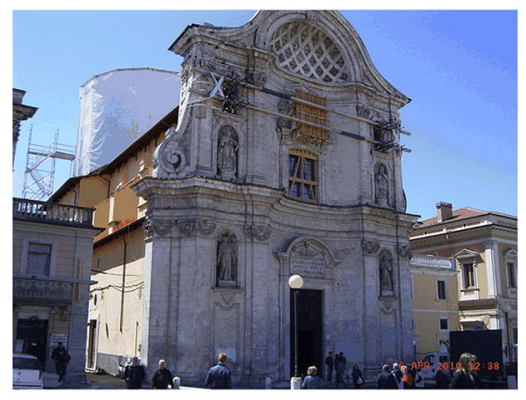

(e)

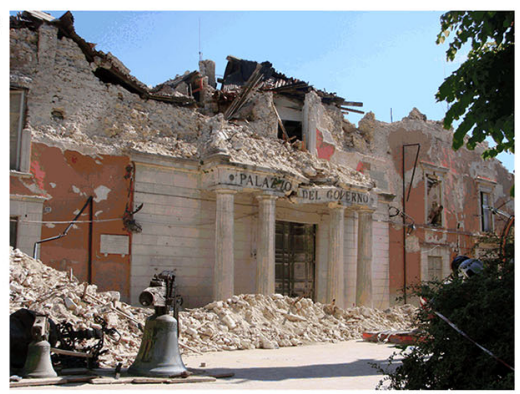

(g)

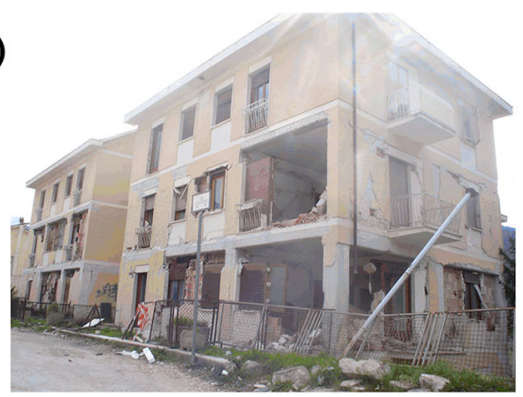

(b)

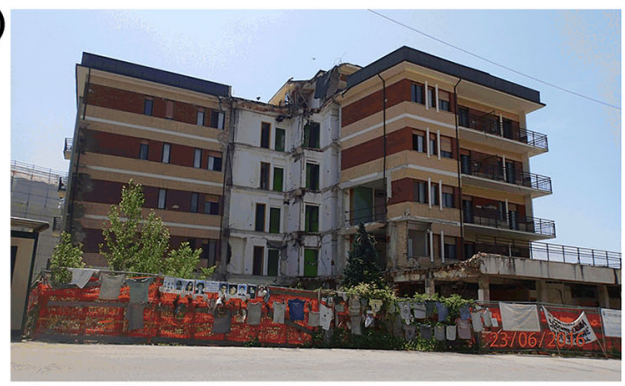

(d)

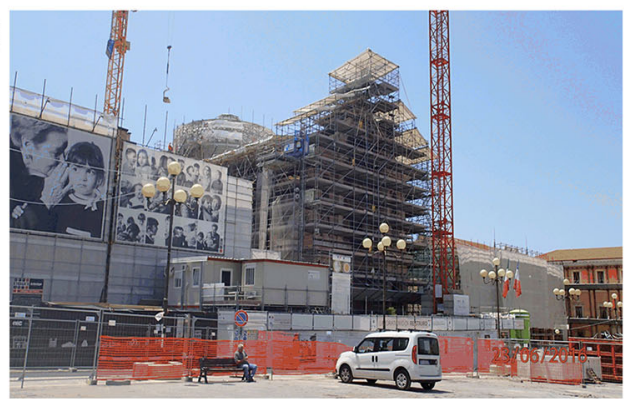

(f)

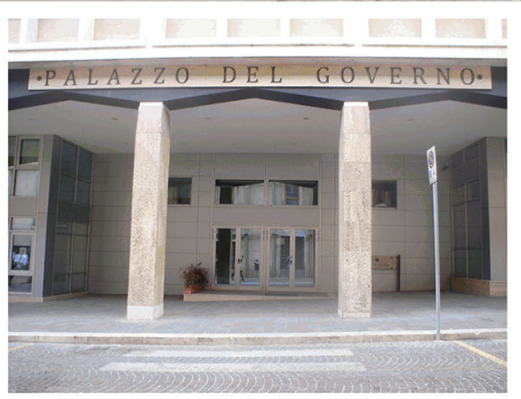

(h)

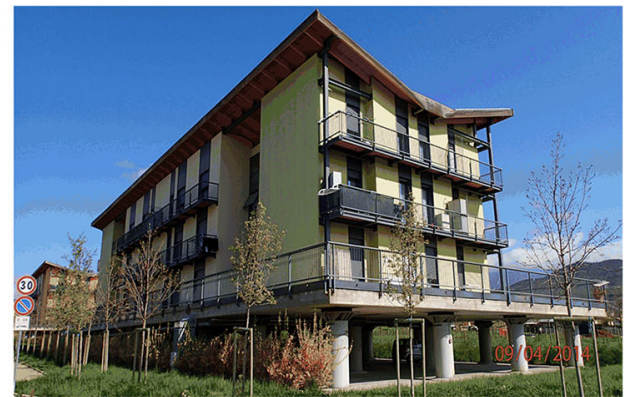

which is another sign of progress in the recovery process. The percentage of buildings demolished reached $3 \%$ (24) in 2014 from just over $1 \%$ (8) in 2012, but this number decreased again to $2 \%$ (18) in 2016. The percentage of damaged buildings remained high at $32 \%$ (239) of the sampling buildings in the city center of L'Aquila in 2014 (Contreras 2015) and slightly decreased to $28 \%$ (214) in 2016. These numbers were the reason to assign the value of " 1 " to the change in building condition indicator for the early recovery and recovery phases.

Using the same sampling area and sampling size (753 buildings) to monitor the building condition change from 2010 to 2016, it was found that the percentage of uninhabited buildings in the former restricted zone has been slightly decreasing since 2010, when $86 \%$ (648) of the buildings included in this sampling were not inhabited. By 2012 the percentage of uninhabited buildings had decreased slightly to $81 \%$ (611), but by 2014 increased to $75 \%$ (568) and by 2016 to $75 \%$ (561). Between 2012 and 2014, 3 new recreation facilities became available, representing a $20 \%$ increase from 15 in 2009 before the earthquake. There was no progress in this kind of building use by 2016. In 2014, the number of commercial facilities available in the sampling zone was 78 , increased by $77 \%$ from 44 before the earthquake. There was no increase in the number of commercial facilities by 2016. Between 2010 and 2016, there has been no increase in the number of educational facilities ( 5 before the earthquake), monuments 
( 2 before the earthquake), and transport facilities ( 8 before the earthquake). In 2016 there was no longer any health (2 before the earthquake) or industrial ( 1 before the earthquake) facility in the sampling zone. Between 2012 and 2014, the number of hotels, offices, and religious facilities increased by 4,21 , and 8 , representing a 33,38 , and $28 \%$ increase from 12 hotels, 55 office facilities, and 29 religious facilities before the earthquake, respectively. From 2014 to 2016, the number of office facilities available in the sampling zone increased by 1 but there was no change in the number of hotels or religious facilities during this time period. The number of residential buildings, 580 before the earthquake, has been steadily increasing from 76 (13\% of the residential buildings in the sampling zone before the earthquake) in 2010, to 79 in 2012, 106 in 2014, and 113 in 2016. These numbers were the reason to assign the value of " 1 " to the change in building use indicator for the early recovery and recovery phases.

Parts of the main hospital were evacuated after the earthquake due to the risk of collapse (Donadio and Povoledo 2009), but it was working normally already in 2014 . The availability of health facilities is not a problem anymore, which explains the value of "0" assigned to the availability of the health facilities and field hospitals required indicators for the relief phase. The repair of the hospital of L'Aquila justifies the value of " 1 " assigned to the indicator health facilities repaired for the early recovery phase.

The emigration rate has soared and employment security has fallen since the earthquake (Venturini and Verlinghieri 2014). This is the reason to assign the value of " 1 " to the emigration rate indicator for the recovery phase. The lack of sufficient facilities in the city center and in the new settlements is the reason for the assignment of the value " 1 " to the availability of education, care, and sports facilities and the availability of commercial and industrial facilities indicators for the relief phase, because this problem is characteristic of this phase. There is a high demand of labor force in the construction industry due to the reconstruction in the city. This is the reason to assign a value " 1 " to the job openings per month and job applicants indicators for the recovery phase.

The hotels available indicator got a value of " 1 " for the early recovery phase, because four of the 12 hotels included in the sampling zone were functioning by 2016 . The relocation of the Government Palace is the reason for the assignment of the value " 1 " to the indicator new public buildings in the affected area, which is more a characteristic of the development phase.

Monuments and conservation buildings have been repaired and reinforced through the years, which explains the assignment of the value " 1 " for those indicators for the early recovery and recovery phases. The same reason explains the assignment of the value " 1 " for the indicator structures repaired in the case of open spaces and parks for the early recovery phase.

\section{Discussion}

The housing erected between 2009 and 2010 in the new settlements to accommodate people left homeless by the earthquake included features such as seismic isolation and solar cells, characteristics that are more closely associated with the development phase of a recovery process (Fig. 4h). But it was still possible by 2014 to find damaged houses in the city center, which is characteristic of the relief phase. This confirms that the boundaries between post-disaster recovery phases are fuzzy.

The lack of employment security is based on the fact that there are no job openings in sectors other than the construction industry and that the reconstruction of the city center will need still more time. Therefore there are no urban facilities that could be sources of employment in the new settlements. Alexander (2012) underlined how the damage to infrastructure and the reduction in services available resulted in a loss of productive employment in L'Aquila. Prior to the earthquake Universitá degli Studi dell'Aquila was the main employer in the city. Following the earthquake conditions became difficult due to the large amount of damage, with some important buildings destroyed. The suspension of enrollment fees also made it difficult for the university to continue to function, and enrollments fell by $6 \%$ over the first three semesters after the earthquake (Alexander 2012).

Only two banks (Fig. 5a, b), one insurance institution (Fig. 5c), and four hotels (Fig. 5d) had opened in the city center by 2016. Most restaurants in the city center had already reopened by 2012 and are located along the main road (Corso Federico II) or close to the main square ( $\mathrm{Pi}$ azza del Duomo). Some of the restaurants that had reopened were closed again by 2014, possibly due to the reconstruction activities that made access for pedestrians difficult and unsafe. This lack of stability in the opening and closing of commercial facilities shows the fuzzy boundary between recovery phases, in this case between the early recovery and the recovery. While in 2012 the city center started to be functional, more work in 2016 necessitated the closure of some commercial facilities, setting this zone back to the early recovery phase.

This situation is encouraging migration away from the area, because a large proportion of the economic activities in L'Aquila takes place in the central business district, referred to by Arens (2014) as the biggest construction site in Europe. There is a strong correlation between the 
Fig. 5 Progress of rebuilding in L'Aquila, Italy, after the 6 April 2009 earthquake: a Savings Bank of Chieti-CarichietiAgency of L'Aquila in 2012, 3 years after the earthquake (Cassa Di Risparmio Della Provincia Di ChietiCarichieti-Agenzia Di L'Aquila); b National Bank of Business in 2012 (Banca Nazionale del Lavoro); c National Institute of Insurance in 2012 (Istituto Nazionale delle Assicurazioni); d Hotel Duca Degli Abruzzi in 2012

Photographs by D. Contreras

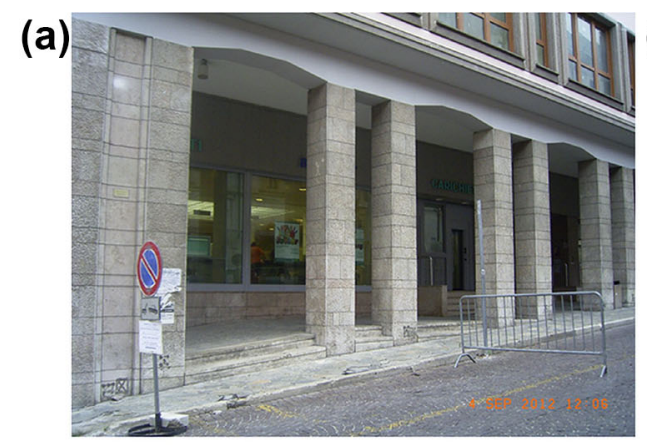

(b)

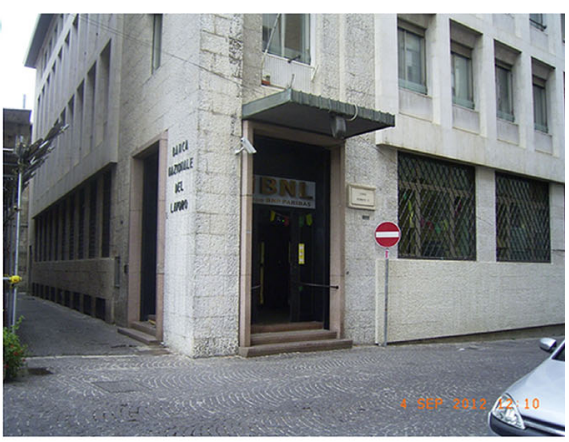

(c)

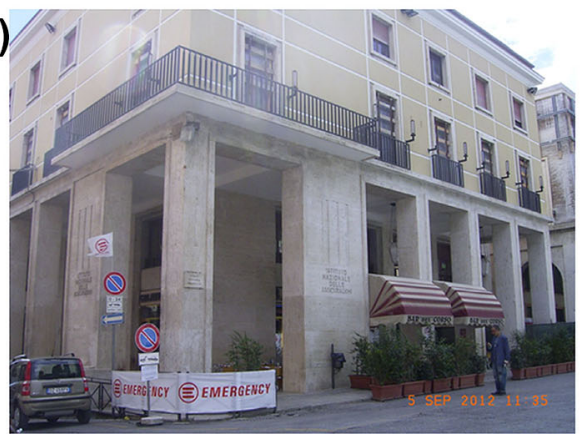

(d)

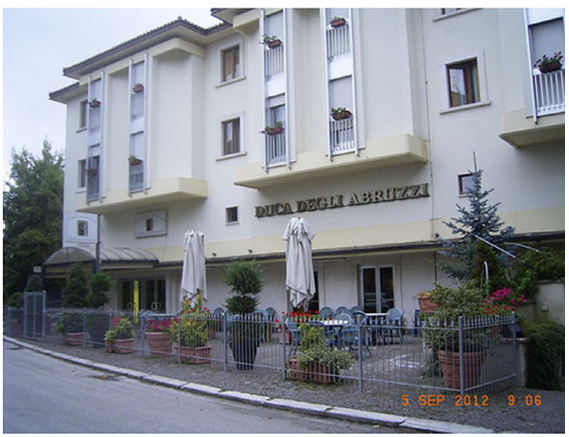

dissatisfaction among people who relocated to new settlements and the distance and travel time to central L'Aquila (Contreras et al. 2013). There were emergent groups that wanted to regain social space for L'Aquila through the location in the new settlements of amenities such as multifunctional centers (including auditorium, library, multimedia, and playground spaces for children). The main objective is to reduce the emigration of young people from the city of L'Aquila (Forino 2014). Most of the new settlements lack any urban facilities, a characteristic of the relief phase when most of the facilities are not available due to damage, but in this case due to the lack of urban planning in the design of the new settlements (Contreras et al. 2013). These problems contrast with the advanced seismic design of the houses, more related to the development phase.

The Government Palace in L'Aquila (Fig. 4e, f) was relocated and reconstructed. The Castello (or Forte Spagnolo) was reopened in 2010, which encouraged the recovery of the city. The Basilica di San Bernardino opened in 2016. Other churches such as the Francesco Di Paola church still required structural support but were open to parishioners. Some churches, such as Santa María del Suffragio in the main square, continued with reconstruction work while remaining open for religious services. Others had been completely repaired by 2014 , such as the Cattedrale Metropolitana dei Santi Massimo e Giorgio and the Basilica Santa Maria di Collemaggio. In 2016, the memory chapel next to the church Santa Maria di Collemaggio opened to visitors. This demonstrates that while some buildings give the impression that the development phase has been reached in L'Aquila, others continue to show characteristics of the recovery or early recovery phases.

Gigantesco et al. (2013) carried out telephone interviews in 2012 with a random sample of 957 adult residents of L'Aquila as part of research into the psychological sequelae of the earthquake. The authors found a prevalence of posttraumatic stress disorder (PTSD) and major depression (MD) even 19 months after the earthquake. These kinds of mental disorders characteristic of the relief phase should not continue for such a long time, but possibly due to the delay in the recovery process in L'Aquila, they continue to be a problem among the population. This confirms that overlap exists between recovery phases, because by the time the interviews were done, L'Aquila was in the transition from the relief to the early recovery phase after the earthquake. This also confirms that in the minds of the affected people the boundaries between the post-disaster recovery phases are fuzzy.

Many tourists were observed visiting the city center in 2012 (Contreras et al. 2014), 2014, and 2016, as confirmed by officials from the Office of Public Reconstruction in the community of L'Aquila. This is promising and confirms that while L'Aquila is still in the early recovery phase the city is on the way to the recovery phase. With respect to tourism, L'Aquila's recovery process can be compared to the recovery process of Christchurch, New Zealand, from two earthquakes in 2010 and 2011. While Christchurch had to close the city center for 2 years, and there are still demolition tasks and empty parcels characteristic of the early recovery phase, the city has managed to advance to the development phase. The institution in charge of 
reconstruction located monuments in some of the empty parcels and built symbolic buildings, such as the Cardboard Cathedral (also called the transitional cathedral) and founded the Quake City museum. A tourist route was designed around the affected area and a temporary shopping mall, called Re:START, was built from shipping containers. Some artists painted murals on the walls of the remaining buildings next to the empty parcels. The planning department has already developed a reconstruction plan for the city center that incorporates changes in urban land use, building density, parks, and roads, and the new buildings include seismic isolation features, all characteristics of the development phase. This is another example of the fuzzy boundaries between the recovery phases.

The relocation of most of the people left homeless by the earthquake in L'Aquila is not proof of recovery. The fact that several churches, which constitute monuments within this historical city, were still undergoing repair and reconstruction 5 years after the earthquake also indicates that the problems associated with the disaster had clearly not yet been overcome. However, the relocation and reconstruction of the Government Palace, the use of seismic isolation in the new settlements, and the inclusion of solar cells on their roofs and balcony handrails (more characteristic of the development phase) while buildings were still being demolished, new buildings erected, and debris cleared within the city, supports the idea that recovery phases have fuzzy boundaries and there are always overlaps between them.

The results of this study suggest that it is not possible to test the recovery following the L'Aquila earthquake against the Kates and Pijawka (1977). It is too difficult to ascertain how long each phase will last because each recovery phase is unique, which confirms the fuzzy boundary hypothesis. It is therefore proposed that, instead of using discrete periods of time, post-disaster recovery should be measured in terms of overlapping time periods. Whether each recovery phase starts earlier or later will depend on the level of damage caused by an earthquake and the vulnerability of the affected area prior to the event.

Further research based on the comparison of the recovery process of multiple case study areas affected by disasters will be necessary to understand whether the fuzzy boundaries and the overlap between post-disaster phases are the result of lack of suitable planning, or whether they are an inherent characteristic of post-disaster phases.

\section{Conclusion}

The binary system used in this study to evaluate the recovery phase achieved for L'Aquila by 2016 can be used to evaluate the progress of the recovery process of any area affected by an earthquake, based on the evaluation of each indicator per dimension. The scores in the case of L'Aquila were assigned based on the monitoring of the recovery process between 2009 and 2016. The scores obtained for each phase gave a realistic assessment of the recovery stage attained in L'Aquila by 2016, because the recovery process in the city included a mixture of characteristics from each of the different post-disaster phases, demonstrating the fuzzy boundaries between the phases.

Most of the indicators identified for the post-disaster recovery were physical and social indicators, followed by smaller numbers of economic, institutional, cultural, and ecological indicators. Further research is required to identify additional institutional and cultural indicators for postdisaster recovery following earthquakes. There are not many ecological recovery indicators to evaluate following an earthquake; these are more important after other kinds of natural disasters such as floods, droughts, and landslides, or events related to human error such as fires, leakages, explosions, or chemical spills.

By 2016 major advances had been made in L'Aquila with respect to providing housing (with seismic isolation and solar cells) for people made homeless by the 2009 earthquake, locating bus stops in the new settlements, creating tax-free areas, and accelerated reconstruction activities in the city center. But L'Aquila was still considered to be in a transition between the early recovery and the recovery phase by the UNDP definition-equivalent to the full-fledged recovery phase of Honjo (2011), the early recovery and reconstruction phases of Brown et al. (2010), the recovery and revitalization phases of Murai (2008), phases II and III of Karatani and Hayashi (2004), the principles and planning and implementation phases of Shaw (2004), the honeymoon/disillusionment and reconstruction phases of SAMHSA (2000), the restoration and replacement and reconstruction phases of Kates and Pijawka (1977) and Vale and Campanella (2005), and restoration and reconstruction I phases of Hogg (1980), because of delays in the removal of debris, the continuing presence of damaged buildings, the lack of satisfaction with the recovery process expressed by the relocated community, and the high unemployment and migration rates.

The results based on observations made and data collected during the field visits in 2010, 2012, 2014, and 2016 $(1,3,5$, and 7 years after the earthquake) have led to the conclusion that determining recovery phases should be based on the goals achieved and selected variables or indicators. Every recovery case is different due to differences in the financial resources available, the political context, the degree of resilience, and the vulnerability level that existed prior to the event. The vulnerability level of the city center in L'Aquila was very high (Alexander 
2010, 2012) because it was an area made up of ancient buildings, built with masonry and without any reinforcement. Additionally, despite that L'Aquila is located in a medium hazard seismic zone there was no pre-impact recovery plan of any kind at the time of the earthquake. It explains the slowness of the recovery process.

Post-disaster phases following an earthquake have fuzzy boundaries and recovery phases are better defined by the objectives achieved within the affected area than by limiting each phase to a specific time period. It is, however, recommended that assessments should be made at specific times during the post-disaster period (for example, 5 and 10 years after the event) as was done in Kobe (Honjo 2011), based on selected indicators, in order to determine the stage of the recovery process achieved. The proposed assessment method provides a means of defining the factors that affect the recovery process and can assist in formulating policies with which to solve the associated problems.

Acknowledgments I am extremely grateful for the research grants awarded in 2013 by the Earthquake Engineering Field Investigation Team (EEFIT). This research was also partly funded by the Austrian Science Fund (FWF) through the GIScience Doctoral College (DK W 1237-N23). I would like to thank the Afro-Asiatisches InstitutSalzburg (AAI Salzburg) for complementary financial support towards this research, and the COLFUTURO foundation for the promotion of this scientific work. Last but not least, thanks to the editors and anonymous reviewers for their contributions to this article.

Open Access This article is distributed under the terms of the Creative Commons Attribution 4.0 International License (http://crea tivecommons.org/licenses/by/4.0/), which permits unrestricted use, distribution, and reproduction in any medium, provided you give appropriate credit to the original author(s) and the source, provide a link to the Creative Commons license, and indicate if changes were made.

\section{References}

Aldrich, D. 2012. Building resilience: Social capital in post-disaster recovery. Chicago: University of Chicago Press.

Alexander, D. 2006. "From rubble to monument" revisited: Modernised perspectives on recovery from disaster. In Postdisaster reconstruction: Meeting stakeholder interests, ed. D. Alexander, C.H. Davidson, A. Fox, C. Johnson, and G. Lizzaralde, 13-22. Florence: Firenze University Press

Alexander, D. 2010. The L'Aquila earthquake of 6 April 2009 and Italian government policy on disaster response. Journal of Natural Resources Policy Research 2(4): 325-342.

Alexander, D. 2012. An evaluation of medium-term recovery processes after the 6 April 2009 earthquake in L'Aquila, central Italy. Environmental Hazards 12(1): 60-73.

Arens, R. 2014. The dispersion of L'Aquila (Die Zerstreung L'Aquilas). Salzburger Nachrichten, 5 April 2014, IX, Wochenende.

BBC. 2014. L'Aquila quake: Scientists see convictions overturned. BBC News, 10 November 2014. http://www.bbc.com/news/ world-europe-29996872. Accessed 27 Jul 2016.
Brown, C., M. Milke, and E. Seville. 2011. Disaster waste management: A review article. Waste Management 31(6): 1085-1098.

Brown, D., S. Platt, and J. Bevington. 2010. Disaster recovery indicators: Guidelines for monitoring and evaluation. Cambridge University Centre for Risk in the Built Environment, University of Cambridge.

Chang, S.E. 2009. Urban disaster recovery: A measurement framework and its application to the 1995 Kobe earthquake. Disasters 34(2): 303-327.

Ciorra, P. 2014. L'Aquila: Five years after the earthquake. The Architectural Review, 28 July 2014. http://www.architecturalreview.com/laquila-five-years-after-the-earthquake/8666396.arti cle. Accessed 18 Aug 2015.

Contreras, D. 2009. Designing a spatial planning support system for rapid building damage survey after and earthquake: The case of Bogota D.C., Colombia. Master's thesis. International Institute for Geo-information Science and Earth Observation (ITC), Enschede, The Netherlands.

Contreras, D. 2015. Spatial indicators of recovery after earthquakes. Doctoral thesis, University of Salzburg, Salzburg, Austria.

Contreras, D., and T. Blaschke. 2016. Measuring the progress of a recovery process after an earthquake: The case of L'AquilaItaly. Presentation at the 6th International Disaster and Risk Conference IDRC Davos 2016, 28 August-01 September, Davos, Switzerland.

Contreras, D., T. Blaschke, S. Kienberger, and P. Zeil. 2013. Spatial connectivity as a recovery process indicator: The L'Aquila earthquake. Technological Forecasting and Social Change 80(9): 1782-1803.

Contreras, D., T. Blaschke, S. Kienberger, and P. Zeil. 2014. Myths and realities about the recovery of L'Aquila after the earthquake. International Journal of Disaster Risk Reduction 8: 125-142.

Contreras, D., T. Blaschke, D. Tiede, and M. Jilge. 2016. Monitoring recovery after earthquakes through the integration of remote sensing, GIS, and ground observations: The case of L'Aquila (Italy). Cartography and Geographic Information Science 43(2): 115-133.

Donadio, R., and E. Povoledo. 2009. Italians comb through ruble after quake. New York Times, 6 April 2009. http://www.nytimes.com/ 2009/04/07/world/europe/07italy.html?_r=0. Accessed 27 Jul 2016.

Esposito, S., S. Giovinazzi, L. Elefante, and I. Iervolino. 2013. Performance of the L'Aquila (central Italy) gas distribution network in the $2009\left(\mathrm{M}_{\mathrm{w}} 6.3\right)$ earthquake. Bulletin of Earthquake Engineering 11(6): 2447-2466.

Forino, G. 2014. Disaster recovery: Narrating the resilience process in the reconstruction of L'Aquila (Italy). Geografisk TidsskriftDanish Journal of Geography 115(1): 1-13.

Geipel, R. 1979. Socio-geografical aspects of a seismic catastrophe [Aspetti sociogeografici di una catas-trofesismica]. Milan: Franco Angeli.

Gigantesco, A., N. Mirante, C. Granchelli, G. Diodati, V. Cofini, C. Mancini, A. Carbonelli, E. Tarolla, V. Minardi, S. Salmaso, and P. D'Argenio. 2013. Psychopathological chronic sequelae of the 2009 earthquake in L'Aquila, Italy. Journal of Affective Disorders 148(2-3): 265-271.

Hogg, S.J. 1980. Reconstruction following seismic disaster in Venzone, Friuli. Disasters 4(2): 173-185.

Honjo, Y. 2011. Implementation of the Kobe City recovery plan. Japan Social Innovation Journal 1(1): 1-11.

Karatani, Y., and H. Hayashi. 2004. Verification of recovery process under the great Hanshin-Awaji earthquake disaster based on the recovery index (RI). In Proceedings of the 13th World Conference on Earthquake Engineering, August 1-6, Vancouver, Canada. Paper No. 1381. http://www.iitk.ac.in/nicee/wcee/ article/13_1381.pdf. Accessed 7 Sept 2016. 
Karatani, Y., and H. Hayashi. 2007. Quantitative evaluation of recovery process in disaster-stricken areas using statistical data. Journal of Disaster Research 2(6): 453-464.

Kates, R.W., and D.J. Pijawka. 1977. From rubble to monument: The pace of reconstruction. In Reconstruction following disaster, ed. J.E. Haas, R.W. Kates, and M.J. Bowden, 1-23. Cambridge: MIT Press.

Murai, M. 2008. Recovery assessment expert hearing sessions. In Joint research project on the assessment methodology for recovery community development, ed. ADRC, DRI, IRP, and UNCRD, 55-59. Hyogo: United Nations.

SAMHSA (Substance Abuse and Mental Health Services Administration). 2000. Training manual for mental health and human services workers in major disasters. Washington, DC: SAMHSA.

Shaw, R. 2004. Earthquake risk perception, community interactions and reconstruction experiences. In Proceedings of the International Conference on Earthquake Hazard Preparedness, Rescue and Recovery, 33-50. 5-9 January 2004, Taipei.

Shohei, B. 2007. The evaluation of the status of disaster areas by using recovery indicators (in the case of the Great Hanshin-
Awaji Earthquake). In Proceedings of the 2nd International Conference on Urban Disaster Reduction, 27-29 November 2007, Taipei.

UNDP (United Nations Development Programme). 2008. UNDP policy on early recovery. http://www.pacificdisaster.net/pdnadmin/data/ original/UNDP_2008_Policy_early_recovery.pdf. Accessed 27 Jul 2016.

UNIFI (Università degli Studi di Firenze). 2009. Integrated health, social and economic impacts of extreme events: Evidence, methods and tools. In Annex 2-Proposal Part B. Florence: Università degli Studi di Firenze.

Vale, L.J., and T.J. Campanella. 2005. Conclusion: Axioms of resilience. In The resilient city: How modern cities recover from disaster, ed. L.J. Vale, and T.J. Campanella, 335-355. New York: Oxford University Press.

Venturini, F., and E. Verlinghieri. 2014. Scarcity, post-scarcity and local community: L'Aquila as a case study. Planum II 29: 51-69.

Wisner, B. 2004. Assessment of capability and vulnerability. In Mapping vulnerability, ed. G. Bankoff, G. Frerks, and D. Hilhorst, 183-193. London: Earthscan. 